\title{
Pengaruh Terpaan Media Berita Hoax di Instagram terhadap Opini Masyarakat Milenials Akan Sumber Berita
}

\author{
Jason Roy, Ahmad Junaidi \\ jasonroyyy@gmail.com, ahmadd@,fikom.untar.ac.id
}

Fakultas Ilmu Komunikasi Universitas Tarumanagara

\begin{abstract}
News that is often popular among the millennial community is hoax news or hoax news that is often shared by a handful of irresponsible elements. Every day a lot of hoax news is shared by people who are not responsible for taking advantage in terms of political excellence or the economy. This hoax news about Covid-19 has a big impact, because Media Exposure for Instagram users who often read or watch a hoax news conveyed by the news, thus changing public opinion to believe the truth of the hoax news. This study aims to provide information on the influence of Instagram Media Exposed hoaxes on Public Opinion. The research method used is quantitative methods. The number of respondents in this study had a score of 70 people who were Instagram users and had seen or watched Hoax news. The data description that was carried out in this research was Validity Test, Reliability Test, Normality Test, Correlation Test, Determination Test, Simple Linear Regression Analysis Test. From the results of the research, it was found that there is an influence of the Instagram hoax news as Media Exposure to Public Opinion in the amount of $58.7 \%$ on the variable Y (Public Opinion). The remaining $41.3 \%$ is influenced by other factors not included in this study.
\end{abstract}

Keywords:hoax, media exposure, public opinion.

\begin{abstract}
Abstrak
Berita yang sering kali populer di kalangan masyarakat milenial ini adalah berita hoax atau berita bohong yang sering dibagikan oleh segelintir oknum yang tidak bertanggung jawab. Setiap harinya banyak berita hoax yang dibagikan oleh masyarakat yang tidak bertanggung jawab untuk mengambil keuntungan dalam segi keunggulan politik maupun perekonomian. Berita hoax tentang Covid-19 ini memiliki dampak yang besar, karena Terpaan Media bagi pengguna Instagram yang sering membaca atau menonton sebuah berita hoax yang disampaikan oleh berita tersebut, sehingga merubah Opini masyarakat menjadi percaya akan benarnya berita hoax tersebut. Penelitian ini memiliki tujuan memberikan informasi pengaruh berita hoax Instagram Terpaan Media terhadap Opini Publik. Metode penelitian yang digunakan yaitu metode kuantitatif. Jumlah responden dalam penelitian ini memiliki nilai hasil 70 orang yang merupakan Pengguna Instagram dan pernah melihat atau menonton berita Hoax. Uraian data yang dilakukan dalam penelitian ini adalah Uji Validitas, Uji Reliabilitas, Uji Normalitas, Uji Korelasi, Uji Determinasi, Uji Analisis Regresi Linier Sederhana. Dari hasil penelitian, ditemukan bahwa terdapat pengaruh dari berita hoax Instagram sebagai Terpaan Media terhadap Opini Publik yaitu sebesar sebesar 58,7\% terhadap variabel Y (Opini Publik). Sisanya sebesar 41,3\% dipengaruhi oleh faktor lain yang tidak ada dalam penelitian ini.
\end{abstract}

Kata Kunci: hoax,terpaan media, opini publik. 


\section{Pendahuluan}

Istilah berita hoax atau berita bohong menjadi hal yang begitu populer di kalangan masyarakat Indonesia. Hoax adalah sebuah informasi yang dihias rangkaian rencana jahat untuk menutupi informasi sebenarnya, dengan kata lain hoax diartikan sebagai upaya membalikan fakta menggunakan informasi yang meyakinkan tetapi tidak dapat diverifikasi kebenarannya (Septanto, 2018).

Salah satu hoax yang banyak dikonsumsi oleh masyrakat adalah Covid-19. Virus Covid-19 adalah virus terbaru yang memicu kekhawatiran khalayak dunia saat ini. Berita - berita tentang virus Covid-19 pun diberitakan dimana - mana, sayangnya diantara sekian banyak berita tersebut, muncul sederet berita palsu alias hoax tentang virus Covid-19.

Kementerian Komunikasi dan Informatika (Kominfo) RI merilis sejumlah kabar hoax soal virus covid-19 yang beredar belakangan ini. Kominfo menyatakan bahwa pemberitaan seperti itu dapat mempengaruhi opini masyarakat akan suatu berita yang disampaikan apakah ada kaitannya tentang terpaan media berita hoax di media sosial terhadap opini masyarakat akan suatu sumber berita.

Hal tersebut menjadi dasar penelitian ini bermaksud untuk menanggapi bahwa terdapat pengaruh antara terpaan media berita hoax media sosial terhadap Opini masyarakat milenial mengetahui banyaknya masyarakat milenial positif dalam mencerna berita media sosial. Hal ini menarik peneliti untuk melakukan penelitian melakukan dengan judul "Pengaruh Terpaan Media Berita Hoax di Instagram Terhadap Opini Masyarakat Milenial akan Sumber Berita (Studi Kasus Terhadap Virus Covid-19)".

\section{Metode Penelitian}

\section{Gambar 1. Kerangka Pemikiran}

\begin{tabular}{|c|c|}
\hline Terpaan Media & Opini Publik \\
\hline 1. Frekuensi & 1. Kepercayaan \\
\hline 2. Durasi & 2. Nilai \\
\hline 3. Atensi & 3. Pengharapan \\
\hline
\end{tabular}

Pada penelitian ini, peneliti memakai cara metode penelitian kuantitatif dan survei sebagai teknik pengumpulan data. Survei dibagikan kepada 70 responden yang merupakan pengguna media sosial Instagram dan pernah membaca/menonton berita hoax Covid-19 di Instagram. Variabel bebas pada penelitian ini adalah Opini Publik atau Pemikiran Masyarakat. Pengukuran data pada penelitian ini menggunakan skala Likerts dengan bobot kategori: (5) Sangat Setuju/SS, (4) Setuju/S, (3) Netral/N, (2) Tidak Setuju/TS, dan (1) Sangat Tidak Setuju/STS.

Populasi pada penelitian ini diambil dari Masyarakat milenial Jakarta Barat yang membaca atau menonton sebuah berita hoax. Sampel adalah bagian dari sejumlah ciri khas yang dimiliki oleh masyarakat yang digunakan untuk penelitian. 
Bila populasi besar, peneliti tidak mungkin mengambil semua untuk penelitian massal karena terbatasnya dana, tenaga, dan waktu, maka peneliti dapat menggunakan sampel yang diambil dari populasi itu (Sujarweni, 2019:65).Maka dari itu penulis memutuskan untuk menetapkan sampel sebanyak 70 orang. Teknik analisis data pada penelitian ini yaitu Analisis Koefisien Korelasi, Koefisien Determinasi Analisis Regresi Linier Sederhana, Uji Validitas dan Uji Reliabilitas.

\section{Analisis dan Pembahasan}

1. Uji Validitas

Tabel 1. Hasil Uji Validitas

\begin{tabular}{|c|c|c|c|}
\hline \multirow{4}{*}{ Variabel } & Butir Indikator & $\begin{array}{c}\text { Corrected } \\
\text { Item Total } \\
\text { Correlation }\end{array}$ & Keterangan \\
\hline \multirow{4}{*}{$\begin{array}{c}\text { Terpaan } \\
\text { Media } \\
\text { (X) }\end{array}$} & Terpaan Media 1 & 0,736 & Valid \\
\cline { 2 - 4 } & Terpaan Media 2 & 0,477 & Valid \\
\cline { 2 - 4 } & Terpaan Media 3 & 0,511 & Valid \\
\cline { 2 - 4 } & Terpaan Media 4 & 0,604 & Valid \\
\cline { 2 - 4 } & Terpaan Media 5 & 0,661 & Valid \\
\cline { 2 - 4 } Opini Publik & Terpaan Media 6 & 0,665 & Valid \\
\cline { 2 - 4 } (Y) & Opini Publik 1 & 0,435 & Valid \\
\cline { 2 - 4 } & Opini Publik 2 & 0,384 & Valid \\
\cline { 2 - 4 } & Opini Publik 3 & 0,658 & Valid \\
\cline { 2 - 4 } & Opini Publik 4 & 0,555 & Valid \\
\cline { 2 - 4 } & Opini Publik 5 & 0,487 & Valid \\
\cline { 2 - 4 } & Opini Publik 6 & 0,373 & Valid \\
\hline
\end{tabular}

(Sumber: Data Primer, diolah dengan SPSS)

Berdasarkan hasil uji validitas, dapat disimpulkan bahwa sebanyak 6 buah penyataan dalam variabel $(\mathrm{X})$ "Terpaan Media" memiliki nilai $r$ hitung $>0,2$ yang berarti pernyataan dari variabel $\mathrm{X}$ telah valid. Begitu juga dengan variabel $\mathrm{Y}$ "Opini Publik" yang sebanyak 6 buah pernyataan dan memiliki nilai $r$ hitung $>0,2$ yang berarti pernyataan dalam variabel telah valid.

\section{Uji Reliabilitas}

Uji reliabilitas dalam penelitian ini bertujuan untuk mendapatkan data yang sesuai dengan kuesioner yang disebarkan. Menurut Ghozali (2015) suatu data yang menggunakan rumus Cronbach's Alpha dengan kategori nilai diatas 0,6. Uji reliabilitas ini dihitung menggunakan aplikasi program SPSS. Berikut adalah hasil dari uji reliabilitas: 
Tabel 2. Hasil Uji Reliabilitas

Hasil Uji Reliabilitas

\begin{tabular}{|c|c|c|}
\hline Variabel & Nilai Cronbach's Alpha & Keterangan \\
\hline Terpaan Media (X) & 0,835 & Reliabel \\
\hline Opini Publik (Y) & 0,726 & Reliabel \\
\hline
\end{tabular}

Sumber: Hasil Pengolahan Data SPSS Versi 15.0

Berdasarkan perhitungan diatas, dapat disimpulkan bahwa pernyataan seluruh pernyataan dalam kuesioner dinyatakan reliabel karena memiliki nilai Cronbach's Alpha diatas 0,6.

\section{Uji Normalitas}

Tujuan dari uji normalitas adalah untuk mengetahui keeratan hubungan antara variabel bebas terhadap variabel terikat. Dengan bantuan aplikasi SPSS, peneliti melakukan dan mendapatkan hasil berikut:

Tabel 3. Hasil Uji Normalitas

\begin{tabular}{|ll|r|r|}
\hline & & \multicolumn{1}{|c|}{ T.X } & \multicolumn{1}{c|}{ T.Y } \\
\hline $\mathrm{N}$ & & 70 & 70 \\
Normal Parameters(a,b) & Mean & 24.74 & 24.77 \\
Most Extreme & Std. Deviation & 3.729 & 3.103 \\
Differences & Absolute & .175 & .094 \\
& Positive & .091 & .056 \\
Kolmogorov-SmimovZ & Negative & -.175 & -.094 \\
Asymp. Sig. (2-tailed) & & 1.463 & .785 \\
\multicolumn{2}{|c|}{ Sumber: Hasil Pengolahan Data SPSS Versi 15.0 }
\end{tabular}

Uji normalitas ini digunakan untuk mengetahui sebuah data normal atau tidak. Hasil analisis diatas menunjukan bahwa ada nilai signifikansi sebesar 0,128 untuk variabel $\mathrm{X}$ dan 0,569 untuk variabel Y. Hasil tersebut menyatakan bahwa distribusi data tidak berdistribusi secara normal karena nilai signifikansi $\mathrm{X}$ dan $\mathrm{Y}>0,05$.

\section{Uji Koefisien Korelasi}

Pengujian koefisien korelasi adalah untuk mengetahui seberapa besarnya keeratan variabel bebas terhadap variabel terkait. Dengan bantuan aplikasi SPSS, peneliti mendapatkan hasil berikut: 
Tabel 4. Uji Koefisien Korelasi

\begin{tabular}{l} 
Model Summary \\
\begin{tabular}{|l|l|r|r|c|}
\hline Model & R & R Square & $\begin{array}{c}\text { Adjusted R } \\
\text { Square }\end{array}$ & $\begin{array}{c}\text { Std. Error of } \\
\text { the Estimate }\end{array}$ \\
\hline 1 & $.766(\mathrm{a})$ & .587 & .581 & 2.008 \\
\hline
\end{tabular} \\
\hline
\end{tabular}

Dari hasil uji diatas, nilai koefisien korelasi $\mathrm{R}$ sebesar 0,766 yang berada diantara interval 0,60-0,799 yang berarti pengaruh Terpaan media mempunyai hubungan yang sedang terhadap Opini Publik.

\section{Uji Koefisien Determinasi}

Pengujian koefisien determinasi berfungsi untuk mengetahui besarnya peranan variabel bebas terhadap variabel terikat. Dengan bantuan program SPSS, peneliti mendapatkan hasil berikut:

\section{Tabel 5. Uji Koefisien Determinasi}

Model Summary

\begin{tabular}{|l|l|r|r|r|}
\hline Model & R & R Square & $\begin{array}{c}\text { Adjusted R } \\
\text { Square }\end{array}$ & $\begin{array}{c}\text { Std. Error of } \\
\text { the Estimate }\end{array}$ \\
\hline 1 & $.766(\mathrm{a})$ & .587 & .581 & 2.008 \\
\hline
\end{tabular}

Sumber: Hasil Perhitungan Data SPSS Versi 15.0

Dari hasil perhitungan tabel diatas, diketahui bahwa nilai koefisien determinasi pada tabel R Square sebesar 0,587 menunjukkan bahwa 58,7\% opini publik dipengaruhi oleh terpaan media sementara sisanya $41,3 \%$ dipengaruhi oleh faktor lain.

\section{Uji Regresi Linier Sederhana}

Analisis regresi linier sederhana adalah suatu cara pendekatan yang digunakan untuk penelitian yang memiliki korelasi antara variabel satu dan lainnya Regresi linier sederhana digunakan hanya untuk satu variabel bebas dan satu variabel tak bebas. Adapun persamaan regresi linier sederhana menurut Siregar (2017:284) Berikut adalah hasil Uji analisis regresi linier sederhana :

\section{Tabel 6. Uji Regresi Linier Sederhana}


Hasil Uji Regresi Linear Sederhana

\begin{tabular}{|c|c|c|c|c|c|c|}
\hline \multirow{2}{*}{\multicolumn{2}{|c|}{ Model }} & \multicolumn{2}{|c|}{$\begin{array}{l}\text { Unstandardized } \\
\text { Coefficients }\end{array}$} & \multirow{2}{*}{$\begin{array}{c}\begin{array}{c}\text { Standardized } \\
\text { Coefficients }\end{array} \\
\text { Beta }\end{array}$} & \multirow[t]{2}{*}{$\mathrm{t}$} & \multirow{2}{*}{$\begin{array}{c}\text { Sig. } \\
\text { Std. Error }\end{array}$} \\
\hline & & B & Std. Error & & & \\
\hline \multirow[t]{2}{*}{1} & (Constant) & 8.990 & 1.622 & & 5.544 & .000 \\
\hline & $T . X$ & .638 & .065 & .766 & 9.840 & .000 \\
\hline
\end{tabular}

$\mathbf{Y}=\mathbf{a}+\mathbf{b} \mathbf{X}$

$\mathrm{Y}=\mathbf{8 , 9 9 0}+\mathbf{0 , 6 3 8 X}$

Dengan keterangan $\mathrm{Y}=$ Opini Publik dan $\mathrm{X}=$ Terpaan Media

Berdasarkan persamaan regresi linear diatas, maka dapat diuraikan sebagai berikut:

1. Nilai Y (Opini Publik) akan tetap sebesar 8,990 konstanta jika nilai X (Terpaan Media) tidak mendapat perubahan, baik pengembangan maupun penyusutan.

2. Jika nilai $X$ (Terpaan Media) mengalami pengembangan nilai sebesar satuan, maka nilai Y (Opini Publik) akan mengalami pengembangan sebesar 0,638 menjadi 9,628 .

\section{Kesimpulan}

Dari hasil penelitian, penulis mendapatkan hasil bahwa terdapat pengaruh antara variabel Terpaan Media (X) terhadap variabel Opini Publik (Y), sehingga melihat Opini masyarakat milenial yang menanggapi terpaan berita hoax dengan baik dalam memilih berita yang ingin di konsumsi. Berdasarkan hasil penelitian terpaan media sosial (X) terhadap Opini publik masyarakat (Y), Ho ditolak dan Ha diterima, artinya bahwa terjadi pengaruh terpaan media terhadap opini publik. Pengaruh terpaan media terhadap opini publik sebesar 58,7\% sedangkan $41,3 \%$ merupakan faktor lainnya.

\section{Ucapan Terimakasih}

Penulis menyampaikan rasa terima kasih kepada Fakultas Ilmu Komunikasi Universitas Tarumanagara, dosen pembimbing, dan seluruh teman yang selalu memberikan semangat dan memberikan saran kepada peneliti.

\section{Daftar Pustaka}

Septanto, H. (2018). Pengaruh Hoax dan Ujaran Kebencian Sebuah Cyber Crime dengan Teknologi Sederhana di Kehidupan Sosial Masyarakat. Jurnal Sains dan Teknologi Kalbi Scientia Vol. 5 No. 2

Siregar, Syofian. (2017). Metode Penelitian Kuantiatif: Dilengkapi Perbandingan

Perhitungan Manual \& SPSS. Jakarta: Prenadamedia Group.

Sujarweni, Wiratna. (2019). Metodologi Penelitian. Yogyakarta: PT. Pustaka Baru. 